\title{
RESEARCH PROGRAM: MODELING OF YOUNG GYMNASTS' TRAINING PROCESS
}

\author{
Khudolii O.M. \\ H.S. Skovoroda Kharkiv National Pedagogical University
}

Corresponding Author: Khudolii, O.M., e-mail: khudolii.oleg@gmail.com

Accepted for Publication: December 20, 2019

Published: December 25, 2019

DOI:10.17309/tmfv.2019.4.02

\begin{abstract}
The study purpose was to substantiate theoretical and methodological grounds and the concept of a research program of the training process based on modeling of individual components of the young gymnasts' training system.

Materials and methods. The study involved: 30 gymnasts - 3rd senior category, 30 gymnasts - 2nd senior category, 26 gymnasts - 1st senior category. Young gymnasts participating in the experiment received athletic titles from the 1st category to master of sports (1st c. - 18 persons, CMS - 15 persons, MS - 12), won competitions of different levels.

To substantiate the research program, the study used the following methods: modeling, systems approach, methods of theoretical analysis and generalization to reveal the essence, leading development trends of the young gymnasts' training system and to define theoretical prerequisites and methodological approaches to its further improvement; pedagogical testing, methods of recording sensorimotor reactions, methods of recording the cardiovascular system state, observation and pedagogical experiment to determine young gymnasts' model characteristics, modes of training loads; methods of mathematical analysis (logistic and asymptotic functions) to determine the regularities of allocating the means of primary focus during motor abilities development, teaching gymnastic exercises and training for competitions; mathematical methods of planning multifactorial experiments to study the regularities of motor abilities development, teaching process and training for competitions. The obtained experimental material was processed using statistical analysis software (SPSS 20).

Results. The developed conceptual approaches to determining the normative characteristics of training loads in the process of young gymnasts' training include: analysis of the effects of different modes of training on a change in the functional state; determination of the optimal increase in the functional state indicators; calculation of a mode of training that can ensure the optimal increase in the indicators of young gymnasts' functional state.

Conclusions. The developed research program makes it possible to define the regularities of motor abilities development, teaching gymnastic exercises and training for competitions; to obtain the models of young gymnasts' training process. As a result of implementing the research program, the study substantiated factorial designs for studying the influence of modes of alternation of exercises and rest on the effectiveness of motor abilities development, motor skills formation, and the effectiveness of training young gymnasts for competitions.
\end{abstract}

Keywords: research program, modeling, training process, young gymnasts.

\section{Introduction}

In scientific publications, the development of research methodology is regarded as an educational process important for the development of physical education and sports (Garcia, Meneguci, Lara da Silveira Zaghi, Damiao, \& Rovigati Simoes, 2016; Koekoelk, Knoppers, \& Stegeman, 2009; Myers, Lee, \& Kostelis, 2018). The improvement of research quality

(C) Khudolii O.M., 2019. is associated with methodology and the use of mathematical statistics (Myers, Lee, \& Kostelis, 2018).

The development of methodological approaches to creating applied programs in physical education and sport (Hongliang, 2013), software development to optimize the lesson planning process ( $\mathrm{Wu}, 2013)$, modeling in biomechanics (Merala, Piziali, 1996; Kirk, 1999), assessment of students' functional state (Wright, 1999; Rink, 2007) are aimed at improving the quality of scientific research. 
Artistic gymnastics studies biomechanical features of performing exercises (Heinen, 2011; Rymal, \& Ste-Marie, 2017), the peculiarities of young athletes' functional state dynamics (Sawicki, Dornowski, Grzywacz, \& Kaczor, 2018; Purenovic-Ivanovic, Popovic, \& Moskovljevic, 2017). Particular attention is paid to studying athletes' anxiety and self-esteem (Milashechkina, Gernet, Timofeeva, Buchnev, Pogorelova, \& Milashechkin, 2019). However, the issue of comprehensive study of young athletes' training process remains under-explored.

The study purpose was to substantiate theoretical and methodological grounds and the concept of a research program of the training process based on modeling of individual components of young gymnasts' training system.

\section{Materials and methods}

\section{Study participants}

The study involved: 30 gymnasts - 3rd senior category, 30 gymnasts - 2 nd senior category, 26 gymnasts 1 st senior category. Young gymnasts participating in the experiment received athletic titles from the 1st category to master of sports (1st c. - 18 persons, CMS - 15 persons, MS - 12), won competitions of different levels.

\section{Study organization}

The study used both philosophical and general scientific methods of research.

The study took into consideration:

- synergistic approach that allowed to view the young gymnasts' training system as having its own logic of self-organization because of its multidimensional manifestations;

- systems approach that allowed to examine the interaction between the training system elements;

- modeling that provided new knowledge about the study object and its practical implementation.

This methodological approach develops a system of knowledge about the regularities of long-term gymnasts' training. It gives grounds for improving the system of training young gymnasts based on modeling of the training process components.

Based on the systems approach and modeling, the study developed the concept of a research program of the training process of young gymnasts aged 7-13. The concept was that to optimize the training process it is necessary to study: models of age-related changes in the functional state of neuromuscular and cardiovascular systems, gymnasts' sports mastery; models of training loads; training process models in order to obtain new information on the dynamics of motor and functional fitness, the duration of using training loads of varying focus and their distribution in the young gymnasts' training process, allocation of time for technical, physical, special motor, functional training in the annual training cycle.

To substantiate the research program, the study used the following methods: modeling, systems approach, methods of theoretical analysis and generalization to reveal the essence, leading development trends of the young gymnasts' training system and to define theoretical prerequisites and methodological approaches for its further improvement; pedagogical testing, methods of recording sensorimotor reactions, methods of recording the cardiovascular system state, observation and pedagogical experiment to determine young gymnasts' model characteristics, modes of training loads; methods of mathematical analysis (logistic and asymptotic functions) to determine the regularities of allocating the means of primary focus during motor abilities development, teaching gymnastic exercises and training for competitions; mathematical methods of planning multifactorial experiments to study the regularities of motor abilities development, teaching process and training for competitions. The obtained experimental material was processed using statistical analysis software (SPSS 20).

\section{Results}

The study assumed that this research program would allow to obtain:

- information on the regularities of interaction between different training exercises in training programs;

- information on the peculiarities of the fatigue process and maintenance of a high performance level that underlie the development of training models;

- models of individual training exercises and their sets.

Before planning the experiment, the study's task is to obtain results that can expand understanding of the comprehensiveness of the young gymnasts' training process. The end result is to obtain a model that takes into account the sum of the system parts and their interactions. Such a model makes it possible to determine what the element serves for within the whole.

The priority of studying the methodology of modeling the training process of gymnasts aged 7-13 is to summarize the results of previous research in gymnastics. An essential issue in the model development is to determine the informative value of features selected for assessing technical, physical, special motor, functional fitness of young gymnasts. The obtained material is used to model a young gymnasts' training process. 
Table 1. Research program in modeling young gymnasts' training process

\begin{tabular}{|c|c|c|c|}
\hline No & Research Task & Research Method & Indicators to record \\
\hline 1 & $\begin{array}{l}\text { To determine informative indicators of } \\
\text { young gymnasts' fitness. }\end{array}$ & Pedagogical testing, factor analysis. & $\begin{array}{l}\text { Indicators of young gymnasts' motor } \\
\text { fitness } \\
\text { Indicators of young gymnasts' functional } \\
\text { fitness. }\end{array}$ \\
\hline 2 & $\begin{array}{l}\text { To determine young gymnasts' model } \\
\text { characteristics }\end{array}$ & $\begin{array}{l}\text { Pedagogical testing, reflexometry, } \\
\text { polydynamometry, correlation } \\
\text { rhythmography and variational } \\
\text { pulsometry. Methods of mathematical } \\
\text { analysis: logistic function }\end{array}$ & $\begin{array}{l}\text { Indicators of young gymnasts' motor } \\
\text { fitness. } \\
\text { Indicators of young gymnasts' functional } \\
\text { fitness }\end{array}$ \\
\hline 3 & $\begin{array}{l}\text { To determine models of loads of } \\
\text { immediate training effect (ITE) and } \\
\text { delayed training effect (DTE) }\end{array}$ & $\begin{array}{l}\text { Mathematical methods of planning } \\
\text { multifactorial experiments }\end{array}$ & $\begin{array}{l}\text { Level of proficiency in exercises. } \\
\text { Grade for performing the exercise. } \\
\text { Indicators of the functional state of } \\
\text { neuromuscular and cardiovascular } \\
\text { systems }\end{array}$ \\
\hline 4 & $\begin{array}{l}\text { To determine the effects of different } \\
\text { training modes on a change in the } \\
\text { functional state of young gymnasts' } \\
\text { bodies }\end{array}$ & $\begin{array}{l}\text { Pedagogical testing, reflexometry, } \\
\text { polydynamometry, correlation } \\
\text { rhythmography and variational } \\
\text { pulsometry. Methods of mathematical } \\
\text { analysis; analysis of variance. }\end{array}$ & $\begin{array}{l}\text { Indicators of the functional state of } \\
\text { neuromuscular and cardiovascular } \\
\text { systems }\end{array}$ \\
\hline 5 & $\begin{array}{l}\text { To determine srtength loads models of } \\
\text { ITE and DTE }\end{array}$ & Polydynamometry, $2 \mathrm{k}$ factorial design & $\begin{array}{l}\text { Absolute strength. } \\
\text { Speed strength }\end{array}$ \\
\hline 6 & $\begin{array}{l}\text { To determine the duration of using high } \\
\text { loads }\end{array}$ & $\begin{array}{l}\text { Methods of mathematical analysis: } \\
\text { logistic function }\end{array}$ & $\begin{array}{l}\text { Indicators of the functional state of } \\
\text { young gymnasts neuromuscular and } \\
\text { cardiovascular systems. }\end{array}$ \\
\hline 7 & $\begin{array}{l}\text { To determine the duration of using } \\
\text { strength loads of varying amount and } \\
\text { focus }\end{array}$ & $\begin{array}{l}\text { Methods of mathematical analysis: } \\
\text { logistic and asymptotic functions }\end{array}$ & $\begin{array}{l}\text { Strength of different muscle groups. } \\
\text { Speed strength }\end{array}$ \\
\hline 8 & $\begin{array}{l}\text { To determine models of teaching motor } \\
\text { actions and movement control. }\end{array}$ & $\begin{array}{l}\text { Methods of mathematical analysis: } \\
\text { logistic and asymptotic functions }\end{array}$ & $\begin{array}{l}\text { Level of proficiency. } \\
\text { Minimum increase in the movement } \\
\text { amplitude. } \\
\text { Grade for performing the exercise. }\end{array}$ \\
\hline 9 & $\begin{array}{l}\text { To determine the regularities of } \\
\text { allocating the means of primary focus } \\
\text { when teaching movements and training } \\
\text { young gymnasts }\end{array}$ & $\begin{array}{l}\text { Methods of mathematical analysis: } \\
\text { logistic and asymptotic functions. } \\
\text { Factorial design }\end{array}$ & $\begin{array}{l}\text { Indicators of the functional state of } \\
\text { neuromuscular and cardiovascular } \\
\text { systems. } \\
\text { Level of proficiency in exercises. } \\
\text { Grade for performing the exercise. } \\
\text { Strength of different muscle groups. } \\
\text { Speed strength }\end{array}$ \\
\hline 10 & $\begin{array}{l}\text { To determine the regularities of } \\
\text { allocating the means of primary focus } \\
\text { during preliminary competitive training } \\
\text { of young gymnasts }\end{array}$ & $\begin{array}{l}\text { Methods of mathematical analysis: } \\
\text { logistic function }\end{array}$ & $\begin{array}{l}\text { Grade for performing combinations. } \\
\text { Strength of different muscle groups. } \\
\text { Speed strength. } \\
\text { Indicators of orthostatic test }\end{array}$ \\
\hline 11 & $\begin{array}{l}\text { To determine models of preliminary } \\
\text { competitive training of young gymnasts }\end{array}$ & $\begin{array}{l}\text { Methods of mathematical analysis: } \\
\text { logistic function. Factorial design }\end{array}$ & $\begin{array}{l}\text { Grade for performing combinations. } \\
\text { Performance analysis of competitive } \\
\text { activity }\end{array}$ \\
\hline
\end{tabular}

Table 1 presents the research program in modeling the process of young gymnasts' training. To solve tasks $3,5,9,11$, the study used $2^{2}, 2^{3}$ multifactorial designs. The result of tasks $3,5,9,11$ is the following models:

$$
Y=b_{0}+b_{1} x_{1}+b_{2} x_{2}+b_{3} x_{1} x_{2}
$$

where $Y$ is the effectiveness of the young gymnasts' training process, $x_{1}$ is the amount in elements, $x_{2}$ is the rest interval, $x_{3}$ is the total time of apparatus activity (30 $\mathrm{min})$. Based on the enumeration of $x_{1}$ and $x_{2}$ values, the optimal variants of primary focus training loads are determined.

The models of teaching motor actions and movement control (task 8) are developed on the basis of mathematical analysis methods of logistic and asymp- 
totic functions. The process of teaching movements is carried out using optimal loads. The study result is the following model:

$$
\mathrm{Y}=\left[\mathrm{A} / 1+10^{(a m+b x)}\right]+\mathrm{C}
$$

where $\mathrm{Y}$ is the effectiveness of teaching motor actions, $\mathrm{X}$ is the number of training sessions held since the beginning of teaching the motor action, $\mathrm{A}$ is the distance between the upper $(\mathrm{A}-\mathrm{C})$ and lower $(\mathrm{C})$ asymptotes, $\mathrm{C}$ is the lower asymptote, the point where the training begins; $\mathrm{a}, \mathrm{b}$ are the parameters that determine the slope, bending, and inflection point of the logistic regression line. The upper asymptote is analyzed to determine the optimal periods of training. The method of finding the optimum is described by Bochkov, Bohomolova, Zhdanova.

For calculation of MINMAX characteristics of logistic functions formulas 3-10 are used:

$$
\begin{gathered}
\mathrm{Y}_{\text {opt.1 }}=\mathrm{Y}_{\mathrm{o}}+0.632\left(\mathrm{~A}+\mathrm{C}-\mathrm{Y}_{\mathrm{o}}\right) \\
\mathrm{Z}_{\text {opt.up }}=0.117\left(\mathrm{~A}+\mathrm{C}-\mathrm{Y}_{\mathrm{o}}\right) \\
\mathrm{Y}_{\text {max }}=\mathrm{Y}_{\text {opt.1 }}+0.632 \mathrm{Z}_{\text {opt.up }}
\end{gathered}
$$

where $Y_{\text {opt.1 }}-$ top optimum, $Z_{\text {opt.up }}-$ zone of top optimum, $\mathrm{Y}_{\mathrm{o}}$ - function's value in the point of bending $(a m / b)$,

$$
\begin{gathered}
\mathrm{Y}_{\text {opt.2 }}=\mathrm{Y}_{\mathrm{o}}+0.368\left(\mathrm{Y}_{\mathrm{o}}-\mathrm{C}\right) \\
\mathrm{Z}_{\text {opt.down }}=0.117\left(\mathrm{Y}_{\mathrm{o}}-\mathrm{C}\right) \\
\mathrm{Y}_{\min }=\mathrm{Y}_{\text {opt.2 }}+0.368 \mathrm{Z}_{\text {opt.down }}
\end{gathered}
$$

where $Y_{\text {opt.2 }}$ - top optimum, $Z_{\text {opt.d }}-$ zone of top optimum, $\mathrm{Y}_{\mathrm{o}}$ - function's value in the point of bending $(\mathrm{am} / \mathrm{b})$

$$
\begin{aligned}
& \mathrm{X}_{\text {max }}=\left\{\lg \left[\mathrm{A} /\left(\mathrm{Y}_{\text {max }}-\mathrm{C}\right)-1\right]-a m\right\} / b \\
& \mathrm{X}_{\text {min }}=\left\{\lg \left[\mathrm{A} /\left(\mathrm{Y}_{\text {min }}-\mathrm{C}\right)-1\right]-a m\right\} / b
\end{aligned}
$$

where $\mathrm{X}_{\max }$ and $\mathrm{X}_{\min }$ are the values of argument in points, where the function takes MINMAX values.

To solve tasks 6,7 with the help of the logistic function, the study analyzes the change in the strength of different muscle groups, the results of motor tests, and orthostatic test index. The lower asymptote is analyzed to determine the optimal duration of using high loads. The optimum is determined by formulas (6-8).

The final stage of the study is to develop a program of young gymnasts' training process for a month and for the period of preliminary competitive training. The basis of programming is the models of various components of the training process. The analysis of the models makes it possible to determine the organization of performing training tasks, the optimal time of using the means of primary focus, and target indicators of control of the training process effectiveness.

The results of the research program implementation are the following:

1. Based on the analysis of scientific and methodological literature, the study found that the system of young gymnasts' training includes the following elements, the combination of which constitutes the method of their training: element I - pedagogical and coaching staff; element II - students; element III - educational organizations; element IV - purpose and tasks of training; element $\mathrm{V}$ - training plans and programs; element VI - training conditions; element VII - exercise method; element VIII - training loads; element IX - academic staff.

The types of relations between these elements are the following: 1) structural; 2) functioning; 3 ) development; 4) control.

Qualitative changes in the development of youth gymnastics result from: the availability of theoretical developments in the technique of performing gymnastic exercises;

the increased amount of training work; change in technology of teaching gymnastic exercises; change in ideas about the possibilities of motor abilities development; improved mechanisms of control over the process of young gymnasts' training at all stages; improved mechanisms of control over the process of highlyskilled athletes' training.

The system of young gymnasts' training is a component of long-term training of athletes and is aimed at creating optimal conditions to achieve maximum results at the stage of higher achievements.

Excessive workload in youth gymnastics creates a deadlock situation, the way out of which requires finding the optimal ratio of time for improving sports mastery, the implementation of social programs and leisure of children and adolescents.

2. The improvement of the young gymnasts' training system requires a comprehensive study on: the state of different sides of young gymnasts' fitness, depending on age and period of training; the ratio of time for different types of training in the monthly cycle of training of gymnasts aged 7-13 in the period of teaching movements, motor abilities development and training for competitions; organization of training loads during classes and a mesocycle at the initial and basic stages of young gymnasts' training; the training process effectiveness, strength, endurance development in different modes of training; the possibilities of dividing the target training task into separate tasks and allocating them in time; a reliable, informative system of control over solving training tasks and regulation of the training process.

3 . The analysis of models of age-related changes in the functional state of neuromuscular and cardiovascular systems, sports mastery of gymnasts aged 7-13 allowed to determine that the athlete model is described by a set of parameters that are related to one another and characterize the state of long-term period of the body's adaptation to physical activity, which determines the effectiveness of training and achievement of competition readiness.

4. The results that are $0.5 \mathrm{~S}$ or more higher than the average can be taken as model characteristics of young gymnasts. The logistic equation describes age-related changes in the latent time of motor response, the error in differentiating the temporal characteristics of move- 
ment, the absolute strength of the forearm extensors, the $\mathrm{R}-\mathrm{R}$ interval duration, the number of exercises of varying complexity learned by gymnasts aged 7-13. A standard scale is used to construct possible gradations of assessment and norms of young gymnasts functional and motor fitness. To assess age-related changes in the functional and motor fitness indicators growth models are used.

5 . The process of training young gymnasts is described by a set of models, including: 1 ) models of agerelated changes in the functional state of neuromuscular and cardiovascular systems, sports mastery of gymnasts aged 7-13;2) models of training loads in apparatus exercises, classes and microcycles of the young gymnasts' training process; 3 ) models of the process of teaching and training young gymnasts.

6. Models of training loads in apparatus exercises, classes and microcycles of the young gymnasts' training process are divided into: 1 ) models of change in the indicators of young gymnasts' fitness after the effect of exercises (ITE); 2) models of change in the indicators of fitness after the effect of exercises in 24 hours (TTE); 3) models of change in the indicators of fitness under the influence of training tasks over a long time period (CTE). The $2 \mathrm{k}$ full factorial designs are used to obtain the models of immediate and delayed training effects. To obtain the models of cumulative training effect logistic and asymptotic functions are used.

7. Training loads can be estimated by amount (for immediate training effect) as follows: decreased indicators - high load, unchanged - average load, improved indicators - low load. The models of ITE loads make it possible to choose, out of multiple variants, the optimal one to achieve the planned effectiveness. It is possible to use the planned effectiveness loads based on the regularities of adaptive reactions. The regression equations that determine the DTE characterize a change in indicators after the first training. The dynamics of change in different indicators in the microcycle under the influence of high loads is described by a logistic function. On the basis of logistic equations, it is possible to select control points to achieve the planned effectiveness, as well as to determine the optimal number of training sessions to achieve the purpose of training. The optimal number of training sessions that consistently use high loads is 2, 3 at the stage of initial training; 3, 4 - at the stage of basic training. An increased index estimate of the orthostatic test indicates the need to proceed to the next type of loads by $30-35 \%$.

8. The correlation between the means of physical and technical training and their combination in the monthly mesocycle training depends on the processes of immediate and long-term stages of young gymnasts' adaptation to physical activity. The ratio of time for physical and technical training is determined for each monthly mesocycle training session. The duration of using the means in the mesocycle is determined based on the graphs of a logistic function; in a training ses- sion - based on the analysis of immediate training effect of loads of varying focus. The sequence of using the means of primary focus is determined based on the positive interaction between the delayed, cumulative training effect of loads of varying focus.

9. The models of the process of teaching and training young gymnasts are divided into: a) models of change in training effectiveness depending on young gymnasts' strength, special motor and functional fitness; b) models of change in training effectiveness depending on the number of training sessions with the use of optimal loads that provide favorable conditions for mastering the movement; $c$ ) models of change in the effectiveness of competitive activity depending on young gymnasts' competitive loads. To obtain models a) and b), a logistic function is used; for models $\mathrm{c}$ ), the regression equations obtained from the analysis of $2^{\mathrm{k}} \mathrm{FFD}$ are used.

10. On the basis of models describing the effects of primary focus loads on the dynamics of motor and functional fitness indicators, the study determined the period for strength development, increase in performance, teaching movement control, teaching gymnastic exercises; it was found that the unit of planning the training process of young gymnasts is a monthly mesocycle. The most important feature of the monthly mesocycle is the completion of training tasks related to strength development, special performance, training and competition readiness.

11. The means of physical training in the monthly cycle are divided into units. The mesocycle has two units of training loads aimed at the development and implementation of the cumulative training effect. The first unit of loads is aimed at the development and implementation of adaptive reactions of the neuromuscular system (training sessions 1-12). The result of the first unit is an increase in strength of corresponding muscle groups and special performance. The second unit of loads is aimed at the development and implementation of adaptive reactions of the cardiovascular system (training sessions 17-24). The result of the second unit is an increase in special performance and the creation of preconditions for effective interaction with the effects of the first unit of the subsequent mesocycle.

12. The process of young gymnasts' strength training can be divided into two closely connected stages. The first stage is the formation of an immediate stage of adapting the neuromuscular system to strength loads. For this, strength loads are used with a recovery period of more than 24 hours in 2-3 (gymnasts aged 7-9), 3-4 (gymnasts aged 12-13) training sessions consecutively. The second stage is the formation of a long-term stage of adapting the neuromuscular system to strength loads. For this, strength loads are used with a recovery period of 24 hours in 3-4 training sessions consecutively. The duration of using strength loads of varying focus is determined based on the the analysis of logistic and asymptotic functions. 
13. The effectiveness of teaching motor actions is determined by the decomposition of training tasks on the basis of objective adaptive reactions of young gymnasts' bodies. The tasks of motor abilities development, an increase in the level of young gymnasts' special motor and functional fitness for mastering gymnastic exercises are solved within the framework of training. The procedure for solving the tasks and selection of training tasks is as follows: 1) motor abilities development, increasing the level of young gymnasts' functional fitness; 2) teaching starting and ending positions; 3 ) teaching actions without which it is impossible to perform an exercise being studied; 4) teaching movement control and preliminary exercises; 5) teaching the whole exercises; 6) increasing the level of young gymnasts' functional fitness; 7) teaching exercises in combination.

14. The effectiveness of young gymnasts' competitive activity is determined by the decomposition of precompetitive training tasks. The procedure for solving the tasks, selection and distribution of training tasks is as follows: 1) increasing the level of the functional state of young gymnasts' cardiovascular and neuromuscular systems; improving the quality of performing combinations; 2) teaching a competitive exercise, improving young gymnasts' technical mastery; 3 ) increasing the level of young gymnasts' functional fitness.

15. The analysis of the models of young gymnasts' training process at the initial and basic stages of training allowed to formulate a number of fundamental guidelines containing general grounds for allocating the means of primary focus in the period of training and teaching movements. The fundamental guidelines are the basis for programming the training process of young gymnasts. The use of programs allows to move the indicators characterizing the state of the neuromuscular and cardiovascular systems, young gymnasts' technical fitness to the zone of above average estimates, while reducing the time of training sessions at the stages of initial and basic training by $20 \%$ and $40 \%$, respectively. The construction of teaching and training based on information models can intensify the training process, increase the effectiveness of control over the process of teaching and training young gymnasts aged 7-13.

16. The developed conceptual approaches to determining the normative characteristics of training loads in the process of young gymnasts' training include: analysis of the effects of different modes of training on a change in the functional state; determination of the optimal increase in the functional state indicators, calculation of a mode of training that can ensure the optimal increase in the indicators of young gymnasts' functional state.

\section{Discussion}

In the course of the research program implementation, the study confirmed that training loads can be estimated by amount (for immediate training effect) as follows: decreased indicators - high load, unchanged average load, improved indicators - low load: (Shlemin, 1968; Zemskov, 1969; Niyazbekov, 1974; Treshcheva, 1981; Smolevskiy, \& Gaverdovskiy, 1999).

The study's findings supplement those of Zatsiorskiy (1969), Petrovskiy (1973, 1976, 1978), Verkhoshanckiy (1972), Platonov (1980, 1984, 1997, 2004) who found that the objects of modeling in the training process are the functional state, the level of motor fitness of young gymnasts, and the effects of individual exercises, lessons, training cycles. The theory of youth sports (Sakhnovskiy, 1997; Nikitushkin, 2005, 2010; Serhiienko, 2009) pays more attention to developing the athlete model and less attention to the impact model. The research program tends to consider the athlete models and impact models as a whole, impact models are central in obtaining information on the development of young gymnasts' training process.

The development of model characteristics of young gymnasts draws on theoretical conclusions formulated by Nabatnikova (1982), Fomin, and Filin (1986). In scientific and methodological literature, there is no consensus on the definition of sports mastery components. Nabatnikova (1982) outlines three models of a young athlete: a model of potential sports opportunities (sports experience, physical development, functional fitness), a model of mastery (general and special physical fitness, technical, tactical, mental fitness), a competitive model (main indicators of competitive activity depending on age characteristics). Mahlo (1986) points out that sports mastery is a field of sports activity, the components of which are exercise, training, competition. Schnabel (1986) singles out competitive and training mastery. Zinner (1987) notes that in sports mastery a significant role is played by athletic performance.

In contrast to the above, the study considered the following as the models of young gymnasts' potential athletic possibilities: latent time of motor response, indicators of movement control, maximum strength of the forearm extensors. Such different opinions are based on the fact that moving indicators to the zone of above average estimates promotes mastering the elements of increased complexity. That is, they point to the potential possibilities for improving sports mastery, the readiness to learn complex movements. The model of sports mastery is the number of increased complexity groups according to the years of study. The studies by Shlemin (1968), Shlemin, and Petrov (1977), Rozin (1979) indicate the importance of determining the number of available movements. However, Shlemin (1968), Shlemin, and Petrov (1977) note the age-related changes in the possibility of teaching motor actions, and Rozin (1979) indicates the approximate number of elements for promising gymnasts to master. In contrast to the data presented in scientific and methodological literature, the study obtained models of increased number of mastered 
exercises of groups A, B, C depending on young gymnasts' age. They can be used as nomograms to determine the level of sports mastery of young gymnasts aged 7-13.

The above indicators characterize the development of motor function of young gymnasts aged 7-13. These data extend those of Shlemin (1968) about the development of motor function in children and adolescents under the influence of gymnastics and are the basis for gradual control over the development of motor function in gymnasts aged 7-13, supplement the findings of Godik (1980, 1982), Zaporozhanov, and Zatsiorskiy (1968), Lebedev (1981), Platonov (1997, 2004) about pedagogical control in sports, and that the key point of pedagogical control is to assess the state of motor function as a leading factor that ensures the growth of athletes' sports and technical mastery.

The novelty is fundamental guidelines on programming the training process, based on the analysis of the models of young gymnasts' training process at the initial and basic stages of training, which contain general grounds for allocating the means of primary focus in the period of teaching and training young gymnasts.

As a result of analyzing the training models, the study obtained new information on the ratio of time for different types of training during the monthly cycle of teaching gymnasts aged $7-10,11-13$ years. The study found that the correlation of means of varying focus and their combination in the training session are determined through the objective processes of immediate and long-term stages of the body's adaptation. Similar data were obtained for the stage of preliminary competitive training of young gymnasts.

The novelty of these findings is the following:

1) In contrast to the data of Shlemin (1968), Shlemin, and Petrov (1977), Rozin (1979), Son (1976), Kirillov (1983), the ratio of time for different types of training in every training session of the monthly cycle was determined;

2) In contrast to Son (1976), Shlemin, and Petrov (1977), Kirillov (1983), the means of varying focus are used in a concentrated way.

The novelty is the information on the optimal organization of training loads in training sessions and mesocycles at the initial and basic stages of young gymnasts' training, which differ from others in the number of training sessions with high loads and their concentrated distribution. The application of variability of training loads in the mesocycle and individual training sessions helps to move the indicators characterizing the state of young gymnasts' neuromuscular and cardiovascular systems to the zone of above average estimates. The above data differ from those of Niyazbekov (1974) both in the number of training sessions with high loads and their concentrated distribution.

The novelty in the method of strength development in young gymnasts is the concentrated use of strength loads with different recovery periods in the optimal time interval. There are two approaches in the theory of strength development: 1) in the process of strength development, every repetitive strength load must be performed in the super-compensation phase (Matveev, 1999; Platonov, 1997, 2004); 2) in the process of strength development during a long stage (2-2.5 months), strength loads are used in the under-compensation phase (Verkhoshanskiy, 1988, 1985; Goncharova, Balashova, \& Korzhenevskiy, 1985; Levchenko, 1984). As a result of implementing the research program, the study substantiated the possibility of combining the two approaches to develop a strategy of strength development in young gymnasts. The prerequisite for combining the two approaches in strength development are the works by Korobkov (1980), Meerson $(1978,1981)$, Platonov (2004), Romanenko (2005) about the development of adaptation reactions. Thus, the development of adaptation reactions begins with dyscrasia, imbalance between function and structure. One way to achieve these changes is to use repetitive loads in the under-compensation phase. In contrast to Verkhoshanskiy (1988), strength loads in the under-compensation phase are applied over a short time interval (2-4 training sessions). It was found that a combined method using the means appropriate for the mode of motor apparatus training in the conditions of young gymnasts' sports activity is effective for the development of maximum strength. This broadens the idea of the possibility to develop maximum strength in young gymnasts. This approach differs from the data of Hauptmanna, Harre (1983) according to which the basic condition for the development of maximum strength is dynamic strength training with a weight of $80-100 \%$ of maximum effort. An important issue in strength training is the development of speed strength in young gymnasts. Thus, for speed strength development Menkhin (1996) suggests one of the variants of three sets of push-ups with a weight of $50-75 \%$ of maximum strength of extensors, with maximum speed until fatigue occurs. Unlike the proposed method, speed strength developed after increasing maximum strength, the number of sets and repetitions per set was limited, as well as the number of consecutive training sessions for speed strength development. Such a structure of speed strength training is conditioned by the dependence between maximum and speed strength, and also by the dependences of: 1) change in the time of performing a single movement on the number of repetitions per set; 2) reduction of time of performing push-ups on the number of sets; 3 ) reduction of time of performing push-ups on the number of training sessions. It was found that the use of strength loads of varying amount and focus during 10-12 training sessions allows to increase the strength of a muscle group by $30-60 \%$, to increase speed strength by $20-35 \%$, to reduce by half the training time for strength develop- 
ment. This supplements the findings of Volkov (1970) about the duration of strength development period in gymnasts; findings of Rozin (1970), Shlemin (1973), Menkhin $(1996,1997)$ about strength development in gymnasts; Menkhin (1989) about speed strength development, as well as the findings of Platonov, and Bulatova (1995), Verkhoshanskiy (1988), Zatsiorskiy (1969, 1970), Kazaryan (1975), Filin (1974), Harre, Hauptmanna (1983), Mahlo (1986), Harre, Leopolda (1986), Paerisch (1961) about strength development in athletes.

The novelty is the substantiation of factorial designs to study the influence of modes of alternation of exercises and rest on the effectiveness of motor abilities and motor skills development in young gymnasts.

The effectiveness of the proposed research program was confirmed by the positive results published in papers by Khudolii, and Iermakov (2011), Khudolii (2012), Khudolii, Ivashchenko, Iermakov, and Rumba (2016).

Thus, this research program in the field of modeling the process of young gymnasts' training creates conditions for finding new resources to improve the effectiveness of young gymnasts' training, to obtain information for the development of expert systems.

\section{Conclusions}

The developed research program makes it possible to define the regularities of the process of motor abilities development, teaching gymnastic exercises, and training for competitions; to obtain models of the young gymnasts' training process. As a result of implementing the research program, the study substantiated factorial designs for studying the influence of modes of alternation of exercises and rest on the effectiveness of motor abilities and motor skills development, and the effectiveness of training young gymnasts for competitions.

\section{Acknowledgement}

The study was carried out in accordance with the comprehensive multi-year research plan of $\mathrm{H}$. S. Skovoroda Kharkiv National Pedagogical University within the topics: "The influence of physical loading on the process of teaching movements and the development of adaptive capacity in children and adolescents" (state registration number 01829011671) (1984-1995); "Modeling of young gymnasts' training process" (19962000); "Methodology and methods of young athletes' training process" (2001-2016).

\section{Conflict of interest}

The author state no conflict of interest.

\section{References}

Hongliang, W. (2013). Data analysis for sports training based on information technology. Information technology and industrial engineering. 48, 411.

Kirk, D. (1999). Physical Culture, Physical Education and Relational Analysis'. Sport, Education and Society, 4(1), 63-73.

Merala, R., Piziali, R.L. (1996). Water SKi Binding Release Loads: Test Method and Results. Astm special technical publication. Skiing trauma and safety. International symposium, 10th, Skiing trauma and safety, 1266, 361-379.

Rink, Judith (2007). Teacher perceptions of a physical education statewide assessment program. Research quarterly for exercise and sport, 78(3), 204-215.

Wright, Steven (1999). A compatative view of teaching practice in Physical Education. International Sports Studies, 21(1), 55-68.

Wu, L. (2013) The application of basketball coach's assistant decision support system. Journal of theoretical and applied information technology, 49(3), 48-52.

Garcia, C. A., Meneguci, J., Lara da Silveira Zaghi, F. H., Damiao, R., \& Rovigati Simoes, R. M. (2016). School Physical Education: The Presence Of Action Research. Educacion Fisica Y Deporte, 35(2), 403-426. https://doi. org/10.17533/udea.efyd.v35n2a07

Koekoelk, J., Knoppers, A., \& Stegeman, H. (2009). How Do Children Think They Learn Skills in Physical Education? Journal of Teaching in Physical Education, 28(3), 310-332. https://doi.org/10.1123/jtpe.28.3.310

Myers, N. D., Lee, S., \& Kostelis, K. T. (2018). Measurement in physical education and exercise science: A brief report on 2017. Measurement in Physical Education and Exercise Science, 22(1), 1-10. https://doi.org/10.1080/10 91367X.2017.1391817

Heinen, T. (2011). Evidence for the Spotting Hypothesis in Gymnasts. Motor Control, 15(2), 267-284. https://doi. org/10.1123/mcj.15.2.267

Sawicki, P., Dornowski, M., Grzywacz, T., \& Kaczor, J. J. (2018). The effects of gymnastics training on selected parameters of anaerobic capacity in 12-year-old boys. Journal of Sports Medicine and Physical Fitness, 58(5), 591-596. https://doi.org/10.23736/S00224707.17.06778-0

Purenovic-Ivanovic, T., Popovic, R., \& Moskovljevic, L. (2017). The contribution of pubertal development to performance scores in high-level rhythmic gymnasts. Acta Gymnica, 47(3), 122-129. https://doi.org/10.5507/ ag.2017.015

Milashechkina, E. A., Gernet, I. N., Timofeeva, O., Buchnev, S. S., Pogorelova, O., \& Milashechkin, V. S. (2019). Ontogenetic Characteristics of Anxiety of Gymnasts of High Sports Qualification. International Journal of Applied Exercise Physiology, 8(2). https://doi. org/10.30472/ijaep.v8i2.581

Rymal, A. M., \& Ste-Marie, D. M. (2017). Imagery Ability Moderates the Effectiveness of Video Self Modeling on Gymnastics Performance. Journal of Applied Sport Psychology, 29(3), 304-322. https://doi.org/10.1080/104 13200.2016.1242515

Shlemin, A.M. (1968). Issledovanie protsessa formirovaniya dvigatel'noy funktsii u detey i podrostkov (na materiale gimnastiki): Dokt. Diss. M. (in Russian) 
Zemskov, E.A. (1969). Issledovanie variantov postroeniya nedel'nykh tsiklov trenirovki gimnastov $v$ sorevnovatel'nom periode: Avtoref. diss. M., 24. (in Russian)

Niyazbekov, U.Kh. (1974). Issledovanie parametrov trenirovochnykh nagruzok i metody upravleniya imi $v$ protsesse podgotovki yunykh gimnastov: Kand. Diss. M. (in Russian)

Treshcheva, O.L. (1981). Otsenka trenirovochnykh nagruzok yunykh gimnastok 8-10 let. Gimnastika: Sb. statey. M.: Fizkul'tura i sport, Vyp. II, 10-13. (in Russian)

Smolevskiy, V.M., \& Gaverdovskiy, Yu.K. (1999). Sportivnaya gimnastika. K.: Olimpiyskaya literatura, 463. (in Russian)

Zatsiorskiy, V.M. (1969). Kibernetika, matematika, sport. M.: Fizkul'tura i sport, 199. (in Russian)

Petrovskiy, V.V. (1973). Kibernetika i sport. Kiev: Zdorov'ya, 110. (in Russian)

Petrovskiy, V.V. (1976). O primenenii metoda modelirovaniya $v$ sportivnoy trenirovke. Modelirovanie funktsional'nogo sostoyaniya sportsmenov razlichnoy podgotovlennosti. Kiev: KGIFK, 4-6. (in Russian)

Petrovskiy, V.V. (1978). Organizatsiya sportivnoy trenirovki. Kiev: Zdorov'ya, 96. (in Russian)

Verkhoshanckiy, Yu.V. (1972). Issledovanie zakonomernostey stanovleniya sportivnogo masterstva $v$ svyazi s problemoy optimal'nogo upravleniy a mnogoletney trenirovkoy (na materiale skorostno-silovykh vidov sporta): Dokt. Diss. M., 326. (in Russian)

Platonov, V.N. (1980). Sovremennaya sportivnaya trenirovka. Kiev: Zdorov'ya, 336. (in Russian)

Platonov, V.N. (1984). Teoriya i metodika sportivnoy trenirovki. Kiev: Vishcha shkola, 352. (in Russian)

Platonov, V.N. (1997). Obshchaya teoriya podgotovki sportsmenov v olimpiyskom sporte. K.: Olimpiyskaya literatura, 583. (in Russian)

Platonov, V.N. (2004). Sistema podgotovki sportsmenov v olimpiyskom sporte. Obshchaya teoriya i ee prakticheskie prilozheniya. K.: Olimpiyskaya literatura, 808. (in Russian)

Sakhnovskiy, K.P. (1997). Teoretiko-metodicheskie osnovy sistemy mnogoletney sportivnoy podgotovki. Dokt. Diss. K.: UGUFVS, 317. (in Russian)

Nikitushkin, V.G. (2010). Mnogoletnyaya podgotovka yunykh sportsmenov: monografiya. M.: Fizicheskaya kul'tura, 240. (in Russian)

Nikitushkin, V.G., Kvashuk, P.V., \& Bauer, V.G. (2005). Organizatsionno-metodicheskie osnovy podgotovki sportivnogo rezerva. M.: Sovetskiy sport, 232. (in Russian)

Serhiienko, L.P. (2009). Sportyvnyi vidbir: teoriia ta praktyka. U $2 \mathrm{kn}$. Knyha 1. Teoretychni osnovy sportyvnoho vidboru. Ternopil: Navchalna knyha Bohdan, 672. (in Ukrainian)

Serhiienko, L.P. (2009). Sportyvnyi vidbir: teoriia ta praktyka. U 2 kn. Knyha 2. Vidbir u rizni vydy sportu. Ternopil: Navchalna knyha - Bohdan, 672. (in Ukrainian)

Nabatnikova, M.Ya. (1982). Osnovy upravleniya podgotovkoy yunykh sportsmenov. M.: Fizkultura i sport, 266. (in Russian)

Fomin, N.A., \& Filin, V.P. (1986). Na puti k sportivnomu masterstvu. M.: Fizkul'tura i sport, 160. (in Russian)
Mahlo, F. (1986). Zur Definition des Begriffs "Sportliche Leistung". Theorie und Praxis der Korperkultur, (3), 188-189.

Schnabel, G. (1986). Sportliche Leistung als Gegenstand der Theorie und Methodik des Trainings. Theorie und Praxis der Korperkultur, (3), 180-188.

Zinner, J. (1987). Zu einigen mit der Sportlichen Leistung und ihrer Struktur im Zusammenhang stehenden Begriffen und ihrer Handhabung in der Leistungsdiaynostik. Theorie und Praxis der Korperkultur, (1), 21-28.

Shlemin, A.M., \& Petrov, P.K. (1977). Sistema podgotovki yunykh gimnastov: Metodicheskoe posobie dlya studentov GTsOLIFKa. M., 97. (in Russian)

Rozin, E.Yu. (1979). Prognostichnost'spetsial'nykh fizicheskikh kachestv $i$ ikh otsenka. Sportivnaya gimnastika: Uchebnik dlya institutov fizicheskoy kul'tury. M.: Fizkul'tura i sport, 260-264. (in Russian)

Godik, M.A. (1980). Kontrol' trenirovochnykh $i$ sorevnovatel'nykh nagruzok. M.: Fizkul'tura i sport, 136. (in Russian)

Godik, M.A. (1982). Pedagogicheskie osnovy normirovaniya i kontrolya sorevnovatel'nykh i trenirovochnykh nagruzok: Dokt. Diss. M., 377. (in Russian)

Zaporozhanov, V.A., \& Zatsiorskiy, V.M. (1968). Izmenenie sostoyaniya sportsmena kak mnogomernyy sluchaynyy protsess. Teoriya i praktika fiz.kul'tury, (1), 5-16. (in Russian)

Lebedev, N.I. (1981). Etapnyy pedagogicheskiy kontrol' podgotovlennosti perspektivnykh gimnastov: Kand. Diss. M., 213. (in Russian)

Son, A.M. (1976). Issledovanie effektivnosti sochetaniya sredstv fizicheskoy i tekhnicheskoy podgotovki i rezhima trenirovochnykh zanyatiy yunykh gimnastov: Kand. Diss. M., 154. (in Russian)

Kirillov, V.E. (1983). Bazovaya tekhnicheskaya podgotovka gimnastov 9-12 let: Avtoref. dis. ... kand. ped. nauk. M., 24. (in Russian)

Matveev, L.P. (1999). Osnovy obshchey teorii sporta i sistemy podgotovki sportsmenov. Kiev: Olimpiyskaya literatura, 317.

Verkhoshanskiy, Yu.V. (1988). Osnovy spetsial'noy fizicheskoy podgotovki sportsmenov. M.: Fizkul'tura i sport, 331. (in Russian)

Verkhoshanskiy, Yu.V. (1985). Programmirovanie $i$ organizatsiya trenirovochnogo protsessa. M.: Fizkul'tura i sport, 176. (in Russian)

Goncharova, G.A., Balashova, N.N., \& Korzhenevskiy, N.A. (1985). Vliyanie razlichnykh variantov raspredeleniya silovykh nagruzok na funktsional'noe sostoyanie yunykh sportsmenov. Teoriya i praktika fizicheskoy kul'tury, (12), 22-25. (in Russian)

Levchenko, A.V. (1984). Dinamika sostoyaniya legkoatletovsprinterov vo vremya vypolneniya bol'shogo ob"ema silovoy nagruzki. Teoriya i praktika fizicheskoy kul'tury, (12), 17-19. (in Russian)

Korobkov, A.V. (1980). Fiziologiya adaptatsii. Normal'naya fiziologiya. M.: Vysshaya shkola, 443-457. (in Russian)

Meerson, F.Z. (1978). Adaptatsiya, deadaptatsiya $i$ nedostatochnost' serdtsa. M.: Meditsina, 344. (in Russian)

Meerson, F.Z. (1981). Adaptatsiya, stress i profilaktika. M.: Nauka, 278. (in Russian) 
Romanenko, V.A. (2005). Diagnostika dvigatel'nykh sposobnostey: uchebnoe posobie. Donetsk: Izd-vo DonNU, 290. (in Russian)

Hauptmann, M., \& Harre, D. (1983). Training zur Ausbildung der Maximalkraftfahigkeit. Theorie und Praxis der Korperkultur, (9), 698-706.

Menkhin, Yu.V. (1996). K probleme obespecheniya nadezhnosti fizicheskoy podgotovlennosti sportsmenov. Teoriya i praktika fizicheskoy kul'tury, (4), 44-48. Rezhim dostupa: http://lib.sportedu.ru/press/ tpfk/1996N4/p44-48.htm

Menkhin, Yu.V. (1997). Deskriptivno-konstruktivnyy podkhod v obespechenii rezul'tativnosti fizicheskikh uprazhneniy. Teoriya i praktika fizicheskoy kul'tury, (10), 7-12.

Menkhin, Yu.V. (1997). Metodologicheskie osnovy fizicheskoy podgotovki gimnastov. Teoriya i praktika fizicheskoy kul'tury, (11), 26, 39-40. Rezhim dostupa: http://lib. sportedu.ru/press/tpfk/1997N11/p26,39-40.htm

Volkov, A.V. (1970). Planirovanie trenirovochnoy nagruzki pri razvitii myshechnoy sily v svyazi s periodicheskimi izmeneniyami funktsional'nogo sostoyaniya dvigatel'nogo apparata sportsmena (na primere gimnastov starshikh razryadov): Kand. Diss. Kiev, 128. (in Russian)

Platonov, V.M., \& Bulatova, M.M. (1995). Fizichna pidgotovka sportsmena. K.: Olimpiys'ka literatura, 320. (in Ukrainian)

Zatsiorskiy, V.M. (1969). Kibernetika, matematika, sport. M.: Fizkul'tura i sport, 199. (in Russian)
Zatsiorskiy, V.M. (1970). Fizicheskie kachestva sportsmena. M.: Fizkul'tura i sport, 200. (in Russian)

Kazaryan, F.G. (1975). Osobennosti vozrastnoy dinamiki myshechnoy sily i problema ratsionalizatsii silovoy podgotovki v shkol'nom vozraste: Dokt. Diss. Erevan, 370. (in Russian)

Filin, V.P. (1974). Vospitanie fizicheskikh kachestv u yunykh sportsmenov. M.: Fizkul'tura i sport, 231. (in Russian)

Harre, D., \& Hauptmann, M. (1983). Kraftfahigkeiten und Krafttraining. Theorie und Praxis der Korperkultur, (3), 205-213.

Harre, D., \& Leopold, W. (1986). Kraftausdauer und Kraftausdauer Training. Theorie und Praxis der Korperkultur, (4-5), 282-292, 355-360.

Paerisch, M. (1961). Problems of strength training. Theorie und Praxis der Korperkultur, (5), 444-449.

Khudolii, O. M., Ivashchenko, O. V., Iermakov, S. S., \& Rumba, O. G. (2016). Computer simulation of Junior gymnasts' training process. Science of Gymnastics Journal, 8(3), 215-228.

Khudolii, O. N. (2012). Regularities of development of motional skills of junior gymnasts. Science in Olympic sports, 1, 36-46.

Khudolii, O., \& Iermakov, S. (2011). Zakonomirnosti protsesu navchannia yunykh himnastiv. Teoriâ ta Metodika Fizičnogo Vihovannâ, (5), 3-18, 35. https:// doi.org/10.17309/tmfv.2011.5.707

\title{
ПРОГРАМА ДОСЛІДЖЕННЯ: МОДЕЛЮВАННЯ ПРОЦЕСУ ПІДГОТОВКИ ЮНИХ ГІМНАСТІВ
}

\author{
Худолій О.М. \\ Харківський національний педагогічний університет імені Г.С. Сковороди
}

Реферат. Стаття: 10 с., 1 табл., 71 джерело.

Мета дослідження - обгрунтувати теоретико-методичні засади, концепцію програми дослідження навчально-тренувального процесу на основі моделювання окремих компонентів системи підготовки юних гімнастів.

Матеріали і методи. У дослідженні прийняли участь: 30 гімнастів - III д.р., 30 гімнастів - II д.р., 26 гімнастів - I д.р. Юні гімнасти, які приймали участь в експерименті, виконали спортивні розряди від 1 до майстра спорту (1 р. - 18 чол., кмс - 15 чол.; мс - 12), ставали переможцями змагань різного рангу.

Для обгрунтування програми дослідження використано такі методи: моделювання, системний підхід, методи теоретичного аналізу та узагальнення для виявлення сутності, провідних тенденцій розвитку системи підготовки юних гімнастів та визначення теоретичних передумов і методологічних підходів ії подальшого удосконалення; педагогічне тестування, методи реєстрації сенсомоторних реакцій, методи реєстрації стану серцево-судинної системи, спостереження і педагогічний експеримент для визначення модельних характеристик юних гімнастів, режимів тренувальних навантажень; методи математичного аналізу (логістична і асимптотична функції) для визначення закономірностей розміщення засобів переважної спрямованості у період розвитку рухових здібностей, навчання гімнастичних вправ і підготовки до змагань; математичні методи планування багатофакторних експериментів для вивчення закономірностей розвитку рухових здібностей, процесу навчання і підготовки до змагань. Отриманий експериментальний матеріал підлягав статистичній обробці з використанням пакетів прикладних програм статистичної обробки даних (SPSS 20).

Результати. Розроблені концептуальні підходи до визначення нормативних характеристик тренувальних навантажень в процесі підготовки юних гімнастів включають: аналіз впливу різних режимів роботи на зміну функціонального стану; визначення оптимального кроку приросту показників функ- 
ціонального стану, розрахунок режиму роботи, який забезпечує оптимальний приріст показників функціонального стану юних гімнастів.

Висновки. Розроблена програма дослідження дозволяє визначити закономірності процесу розвитку рухових здібностей, навчання гімнастичних вправ і підготовки до змагань; отримати моделі процесу підготовки юних гімнастів. У результаті реалізації програми дослідження обгрунтовані плани факторних експериментів для вивчення впливу режимів чергування вправ і відпочинку на ефективність розвитку рухових здібностей, формування рухових навичок у юних гімнастів і ефективність підготовки до змагань.

Ключові слова: програма дослідження, моделювання, процес підготовки, юні гімнасти.

\title{
ПРОГРАММА ИССЛЕДОВАНИЯ: МОДЕЛИРОВАНИЕ ПРОЦЕССА ПОДГОТОВКИ ЮНЫХ ГИМНАСТОВ
}

\author{
Худолей О.Н. \\ Харьковский национальный педагогический университет имени Г.С. Сковороды \\ Реферат. Статья: 10 с., 1 табл., 71 источник.
}

Цель исследования - обосновать теоретико-методические основы, концепцию программы исследования учебно-тренировочного процесса на основе моделирования отдельных компонентов системы подготовки юных гимнастов.

Материалы и методы. В исследовании приняли участие 30 гимнастов - III д.р., 30 гимнастов - II д.p., 26 гимнастов - I д.р. Юные гимнасты, принимавших участие в эксперименте, выполнили спортивные разряды от 1 до мастера спорта (1 p. - 18 чел., КМС - 15 чел.; мс - 12), становились победителями соревнований различного ранга.

Для обоснования программы исследования использованы следующие методы: моделирование, системный подход, методы теоретического анализа и обобщения для выявления сущности, ведущих тенденций развития системы подготовки юных гимнастов и определения теоретических предпосылок и методологических подходов дальнейшего усовершенствования; педагогическое тестирование, методы регистрации сенсомоторных реакций, методы регистрации состояния сердечно-сосудистой системы; наблюдение и педагогический эксперимент для определения модельных характеристик юных гимнастов, режимов тренировочных нагрузок; методы математического анализа (логистическая и асимптотическая функции) для определения закономерностей размещения средств преимущественной направленности в период развития двигательных способностей, обучения гимнастических упражнений и подготовки к соревнованиям; математические методы планирования многофакторных экспериментов для изучения закономерностей развития двигательных способностей, процесса обучения и подготовки к соревнованиям. Полученный экспериментальный материал подлежал статистической обработке с использованием пакетов прикладных программ статистической обработки данных (SPSS 20).

Результаты. Разработанные концептуальные подходы к определению нормативных характеристик тренировочных нагрузок в процессе подготовки юных гимнастов включают: анализ влияния различных режимов работы на изменение функционального состояния; определение оптимального шага прироста показателей функционального состояния, расчет режима работы, который обеспечивает оптимальный прирост показателей функционального состояния юных гимнастов.

Выводы. Разработана программа исследования позволяет определить закономерности процесса развития двигательных способностей, обучения гимнастических упражнений и подготовки к соревнованиям; получить модели процесса подготовки юных гимнастов. В результате реализации программы исследования обоснованы планы факторных экспериментов для изучения влияния режимов чередования упражнений и отдыха на эффективность развития двигательных способностей, формирование двигательных навыков у юных гимнастов и эффективность подготовки к соревнованиям.

Ключевые слова: программа исследования, моделирование, процесс подготовки, юные гимнасты.

\section{Information about the authors:}

Khudolii O.M.: khudolii.oleg@gmail.com; http://orcid.org/0000-0002-5605-9939; Department of Theory and Methodology of Physical Education, H. S. Skovoroda Kharkiv National Pedagogical University, Alchevskikh St, 29, Kharkiv, 61002, Ukraine.

Cite this article as: Khudolii, O.M. (2019). Research Program: Modeling of Young Gymnasts' Training Process. Teoriâ ta Metodika Fizičnogo Vihovannâ, 19(4), 168-178. https://doi.org/10.17309/tmfv.2019.4.02

Received: 10.11.2019. Accepted: 20.12.2019. Published: 25.12.2019

This work is licensed under a Creative Commons Attribution 4.0 International License (http://creativecommons.org/ licenses/by/4.0). 